Article

\title{
Is Population Growth an Environmental Problem? Teachers' Perceptions and Attitudes towards Including It in Their Teaching
}

\author{
Iris Alkaher $1,2, *$ (i) and Nurit Carmi ${ }^{2}$ \\ 1 Faculty of Science, Kibbutzim College of Education Technology and the Arts, Tel Aviv 6250769, Israel \\ 2 Department of Environmental Sciences, Tel-Hai Academic College, Upper Galilee 1220800, Israel; \\ nuritcar@telhai.ac.il \\ * Correspondence: iris.alkaher@smkb.ac.il
}

Received: 14 March 2019; Accepted: 28 March 2019; Published: 3 April 2019

\begin{abstract}
Population growth (PG) is one of the drivers of the environmental crisis and underlies almost every environmental problem. Despite its causative role in environmental challenges, it has gained little attention from popular media, public and government agenda, or even from environmental organizations. There is a gap between the gravity of the problem and its relative absence from the public discourse that stems, inter alia, from the fact that the very discussion of the subject raises many sensitive, complex and ethical questions. The education system is a key player in filling this gap, and teachers have an opportunity to facilitate the discussion in this important issue. While educators mostly agree to include controversial environmental topics in school curricula, calls for addressing PG remain rare. This study explores teachers' perspectives of PG as a problem and their attitudes towards including it in their teaching, focusing on environmental and non-environmental teachers. While perceiving PG as an environmental problem and supporting its inclusion in schools was significantly higher among the environmental-teachers, similar concerns were reported by all the teachers concerning engaging students in discourse around this controversial issue. This consensus indicates the limited impact of knowledgeability on teachers' intentions to address PG in class. Teachers' challenges reflect the dominant Israeli sociocultural norms, religious values and the national pronatalist ideologies. The findings demonstrate how the absence of PG from the public discourse and from school curricula influences teachers' motivation to address it in class. This study highlights the necessity to encourage teachers to address PG in their teaching, even in this reality, by providing them with appropriate tools that will enable them to successfully engage students in this controversial issue.
\end{abstract}

Keywords: population growth; controversial environmental issues; controversial teaching issues

\section{Introduction}

It is widely agreed among scientists from various disciplines that the global environmental crisis is caused by the impact of human activity on the environment. This impact has been described in the literature as a product of three factors that form the mathematical notation of I = PAT, in which P represents population size, A represents affluence and T represents technology [1]. There has been a debate on their relative importance, and some scientists have suggested other factors that contribute to the environmental crisis. Hynes [2], for example, argued that key structural factors that reflect elements of social and environmental justice should be added to the formula. Chertow [3] argued that the relative influence of $\mathrm{T}$ (technology) on $\mathrm{I}$ is so huge that it may reverse the effects of $\mathrm{P}$ and I. Waggoner and Ausubel [4] offered an extension of the I = PAT formula by adding component 
forces of environmental impact. In his book Collapse, Diamond [5] listed five factors that drive and characterize environmental and social collapse that are related to societal and ecological circumstances and constraints. The widely cited I = PAT formula, which is implicitly framed in neo-Malthusian terms [6], has been criticized for overlooking the interactions among the terms for omitting the influence of social organization, cultural and institutional adaptations, trade, and other factors, and for the assumption of linearity of the relationship between the terms $[7,8]$. Either way, it is accepted that if there are too many people, even the most wisely managed technology will not keep the environment from being overstressed [1] and that no environmental problem is made easier by increasing the population [9]. In other words, the dichotomic view that makes a distinction between the effect of PG versus overconsumption on the environment and on human quality of life is misleading. As Ehrlich [10] concisely phrased it: "the argument whether it's population or consumption is like arguing whether the area of a rectangle comes more from its length or its width". Other scientists support his view [11]. Moreover, Crist et al. [11] call to move beyond the prevailing dichotomy not only between PG versus overconsumption, but also between the Global North and Global South, which they claim is "becoming outmoded" by the rapid growth of middle-class consumers in developing countries.

Of all the factors known to drive the environmental crisis, PG has scarcely been studied, and is mostly absent from worldwide public discourse and from national agendas and policy institutions around the world. The literature points out several reasons for this: the first being that PG is considered, among other environmental issues, to be complex and controversial in nature, involving conflicting values and interests. Similar to other controversial environmental issues, Cotton [12] noted that PG is poorly understood by the general public, and even scientists argue and debate about the cause-effect characteristics of this topic as an environmental problem. Other scholars suggest that the limited understanding of the public regarding the implications on humankind and on the environment leads people to fail to make the connection between PG and environmental degradation [13,14]. Other reasons mentioned in the literature for the absence of PG in the public discourse relate to sociocultural and religious attributes. Controlling PG stands in strong conflict with religious faith and certain sociocultural norms in various societies that encourage high birth rates and the creation of large families $[15,16]$.

Researchers who do recognize the necessity to include PG in the public discourse are calling for PG to be addressed through the education system, seeing it as playing a central role in changing society's perceptions, attitudes and behavior $[13,14,17,18]$. They claim that the education system could change learners' attitudes towards PG through increasing their awareness regarding PG as a problem and improving their knowledge of its cause-effect characteristics. These researchers see PG as a necessary topic to address in the education system among other environmental problems, such as global climate change (GCC), which are also not well understood and rarely included in the public discourse.

Education for sustainability (EfS) seems the appropriate approach to address the socio-ecological consequences of PG and to include in school education curricula. EfS emphasizes the roots of current problems, and aims to provide a new educational approach that seeks to empower people and communities to assume responsibility for developing a sustainable future and environmental stewardship $[19,20]$. In addition, EfS is seen as environmental education that incorporates the sociopolitical and sociocultural aspects of human relationships into the environment [21].

Perceiving teachers as important change agents in society designates them as having a crucial role in achieving the objectives of EfS among learners. In this context, teachers are expected to increase learners' awareness of PG, while acknowledging the controversial nature and sensitivity of this topic. They are also expected to discuss with their students possible solutions that would address the consequences of PG in a way that enables a sustainable future for humankind and the environment. Alongside the significant role teachers play in raising students' awareness of PG and its implications, it should be remembered that the teachers themselves are citizens of a particular society, influenced by cultural, religious and/or political values. This raises several general questions concerning addressing 
this issue in school teaching: Do teachers themselves perceive PG as a problem and, if not, is it plausible to expect them to teach a topic that they feel in contradiction with? Do teachers have the motivation and willingness to include this issue in their teaching, despite its absence from the school curriculum? If not, why, and what would increase their motivation to do so? Do teachers feel that they have the necessary knowledge and the appropriate teaching skills to address such a loaded issue?

\subsection{Research Objective and Questions}

This study attempts to address the questions presented above, focusing on the perspectives of teachers regarding PG as an environmental problem and their attitudes towards including it in their school teaching. Seeing the central role of teachers as social agents of change, it is important to understand their attitudes towards this issue, their reasons for including or excluding it in their teaching, and the challenges they expect to face if they do decide to include it. Exploring teachers' perspectives could lead to a better understanding of the opportunities for teaching about PG, how to include it in school curricula, and how to assist teachers who are willing to engage their students in this issue or are struggling with the decision to do so.

Since PG influences different aspects of people's lives, such as quality of life and well-being, and since the consequences of PG are not limited to environmental degradation, but also to social aspects, it is most reasonable to expect that educators from various disciplines would address this topic and not only educators who teach environmental-oriented subjects, such as science and geography teachers. For this reason, in this mixed-method study, we chose to compare the perspectives of teachers from two groups of teachers who have an academic background in environmental-oriented programs (hereafter called E-teachers) and teachers who have an academic background in non environmental-oriented programs (hereafter called non-E teachers). We assumed that teachers who are graduates of academic environmental-oriented programs have been constructively and explicitly exposed to the topic of PG during their studies. As a result, their awareness regarding its impact on the environment and on human quality of life, their willingness to include this topic in school teaching, and their competence to do so will be higher in comparison to teachers who have not been exposed in a similar way to PG in their academic studies.

In line with this assumption, we asked the following specific research questions:

(1) Do teachers perceive PG as an environmental problem, and do E- and non-E teachers differ in their perceptions?

(2) What are teachers' considerations for bringing any environmental topic into the classroom?

(3) How do E- and non-E teachers perceive embedding the issue of PG into their teaching, and what are their considerations concerning including or excluding this topic in the classroom?

This study is pioneering in the sense that, to our knowledge, the perceptions of the lay public towards PG as an environmental problem have never been explored; neither have the perceptions of educators towards PG and their attitudes towards including this topic in their school teaching. Investigating this issue may lead to a better understanding of educators' perspectives towards PG as an environmental problem and a central factor contributing to the environmental crisis, as described earlier. Given that the way people perceive ecological problems and evaluate their severity has a crucial impact on their own motivation to address them, understanding how educators, as change agents, evaluate PG could shed light on the possibilities for implementing it in the classroom: Would they agree to address PG as a problem with their students, and under what conditions? If not, why not?

\subsection{The Contribution of Population Growth to the Environmental Crisis and the Absence of the Topic from the Public Discourse}

The enormous contribution of human PG to the environmental crisis is indisputable according to environmental scientists. Some important milestones in establishing this recognition are Thomas Malthus' An Essay on the Principle of Population, [22], Paul R. Ehrlich's The Population Bomb [13], 
the joint statement of the National Academy of Sciences and the British Royal Society's urging world leaders to brake PG before it is too late [23], and the petition signed by 1600 scientists from around the world (including 99 Nobel laureates) calling on all humanity to stop PG before the environment is completely destroyed [24]. The ecological consequences caused by PG include air and water pollution, soil deterioration, accelerated extinction of biodiversity, climate change and destruction of other interdependent ecosystems that sustain life [25,26]. The implications of these ecological consequences relate to every aspect of life, at the personal, social, political and global scales $[6,27,28]$, and pose a threat to the survival of mankind.

Despite the central contribution of PG to the environmental crisis, relatively little attention has been paid to the issue, either by the popular media, or by leading environmental science and policy institutions, environmentalists and environmental organizations or educators in diverse disciplines [9,29-32]. This study attempts to address this gap, focusing on educators' perspectives on the issue and their attitudes towards including the topic of PG within schools.

Aside from the consensus regarding the grave implications of PG, a second consensus is evident: the reluctance to deal with the issue [11,32-36]. This reluctance is illustrated by a cartoon showing reporters and photographers covering the Paris climate change summit in 2015, completely ignoring or missing the presence of a large elephant that says, "overpopulation" [37]. The disregard for PG stems from several reasons: the controversy it evokes [32,38], humans' evolutionary imperative to reproduce $[9,27,39]$, lack of understanding of the nature of exponential functions [33], and characteristic silencing of discourse on the subject, which foreclose public debates and subject them to critical analysis [36]. Crist et al. [11] add further explanations for the "silence enveloping population matters".

\subsection{Factors Influencing Perceptions of Severity of Problems}

The absence of the topic of PG from the public discourse worldwide may influence the way people perceive the severity of the problem. According to the research literature, factors that influence people's perceptions of severity can range from demographic and sociological factors to personality or psychological factors and risk attributes [40-43]. For the purpose of this study, we present the following attributes that have been cited as strongly related to environmental problems [44]: (1) the perceived certainty of a problem realization [45]; (2) the perceived imminence of the problem [46-49]; (3) the perceived spatial proximity, which is the perceived geographic distance or localization of the problem relative to the person [42]; (4) the perceived potential for personal harm [48,49]; $(5)$ the perceived predictability of the problem [48,49]; and (6) the intensity of emotion that arises at the thought of the problem; specifically, the level of the negative emotion, i.e., anger, sadness, fear, disgust, etc. [50-52].

\subsection{Challenges in Teaching Controversial Environmental Issues}

Environmental issues are often complex and controversial in nature, and involve conflicting values and interests, as described above. They are poorly understood by the general public, and sometimes even scientists argue and debate about the existence of certain environmental problems and their cause-effect characteristics [12]. This situation may be problematic for teachers whose role is to present such issues to their students in unbiased and coherent ways. As a result, in many cases teachers tend to present such controversial topics in a simplistic way instead of teaching them in a way that creates deeper understanding [53-55]. Regardless of the contribution of engaging students in debates around controversial topics in order to improve their critical thinking skills [56,57], the literature in this arena strongly indicates that teachers struggle to teach controversial environmental issues, or even avoid including such topics in their teaching, for several reasons. Some of the reasons relate to the controversial, complex and transdisciplinary nature of the issues and to the strong influence of such issues on non-scientific aspects, with respect to possible solutions to the problem [58]. Other reasons focus on teachers' lack of confidence to teach issues that they feel they lack sufficient knowledge about or lack appropriate pedagogical strategies or experience to teach them [54,59]. Teachers also report that the absence of specific topics from the national standards and from their curricula, as in the case of GCC 
in the US, discourages them to include such topics in their teaching, since their curricula are already overstuffed [60]. Teaching GCC is a prominent example for such teaching challenges. It is perceived as a challenging topic by teachers since it is controversial in relation to the scientific aspects of the issue itself and since the experts themselves considerably disagree about effective ways to address the social, economic, cultural, ethical and other aspects [58]. In addition, competing environmental and political interests create a conflict between protecting the environment by combusting less fossil fuels and securing the interests of the national economy. Such conflicts can confuse teachers and discourage them from teaching this topic [61].

While scientists and educators mostly agree to include controversial environmental topics such as GCC in school curricula, and consider such issues crucial topics to discuss and debate within schools, calls for explicitly including the topic of PG in connection with the environmental crisis in the school discourse remain relatively rare. Among those in favor are researchers who claim that a first step to solving PG is educating students to perceive it as an environmental problem and raising their awareness of this issue; for example, Bridgeman [9], and others who suggest that the education system should open up discussions with students about optional solutions to PG, such as having one less child; for example, Wynes and Nicholas [62]. Even when students are explicitly exposed to the topic of PG, in most cases this exposure does not include a value-oriented discussion that confronts students with its moral aspects. For example, some middle-school mathematics students in the U.S. were engaged in creating and analyzing mathematical models of PG to develop their mathematical generalizations [63], but their teacher did not use this experience as an opportunity to involve her students in a relevant debate on how PG impacts human life.

Currently, calls for including PG in school curricula as an explicit ethics-oriented topic are still very rare, reflecting the high level of controversy that this topic generates among the general public, as well as among educators, including environmental educators. This study attempts to shed light on teachers' perspectives and reasons to address or ignore this topic in their teaching, focusing on similarities and differences between E- and non-E educators.

\subsection{The Topic of Population Growth in the School Curriculum in Israel}

The topic of PG as a main contributor to the environmental crisis is almost absent from the school curriculum in Israel. PG and its socio-environmental consequences are explicitly included only at high-school level as part of the curricula of two subjects designed for majors: "environmental studies" and "geography and environmental development studies". Since high-school students in Israel can choose their major subject from many available options and since PG as an environmental issue is absent from the elementary and middle-school levels, it means that only a small fraction of Israeli students are introduced to this topic during their K-12 studies. As part of the environmental studies curriculum, PG is included in two chapters: "Ecosystem and human-environment relationships" (a mandatory/elective chapter) and "Environmental management" (an elective chapter) [64]. In these chapters, PG is presented as a concept that should be explicitly introduced and discussed with students. The central goal of the mandatory part of the ecosystem chapter is to deepen students' understanding of concepts, principles and processes related to the ecosystem and human-environment relationships, and develop their capabilities to address environmental problems related to this subject in decision-making in their own lives. In this part of the chapter, PG is described as a central cause for loss of biodiversity. In the elective part of the chapter, the demographic changes in human population around the world as a result of the processes of immigration and urbanization are included in the curriculum, with no additional goals regarding the consequences of PG. In the environmental management chapter, PG is introduced as a central factor (together with overconsumption) for the degradation of natural resources, and as a problem that should be addressed at all levels (i.e., local and global). The central goal of this chapter is to deepen students' understanding of concepts, principles and processes related to environmental design and management, and to develop their capabilities to address such problems in their decision-making. The content of this chapter includes relevant concepts related to PG, such as 
population explosion and exponential growth and relevant theories such as that of Malthus and neo-Malthusian theories.

In geography studies, PG is included in the elective chapter of "Humans in the sociocultural sphere" under the subject of "Demographic changes in human population" [65]. Two goals of this chapter explicitly address the complexity and controversy of PG as a problem. The first goal states that students should be acquainted with the demographic diversity between developed and developing countries and made aware of the factors that trigger demographic processes. They should also understand the ethical aspects of governmental policies of birth management (birth control or encouragement). The second goal states that students should develop their abilities to analyze and evaluate the factors that influence immigration between countries and the short-term and long-term consequences of such immigration on the relevant countries. They should also be exposed to the ethical dilemmas between universal humanistic values and legitimist governmental interests and considerations of the country that welcomes immigrants. Similar to the curriculum of environmental studies, this chapter also includes relevant concepts, such as population explosion and the Malthusian and neo-Malthusian theories. Additionally, it includes more controversial concepts such as birth management policy, productive population and non-productive population.

In biology studies for high-school majors, the inclusion of PG is implied to some extent. The idea that PG is responsible for environmental problems is clearly presented in the mandatory part of the ecosystem chapter, but addressing this issue further on in the goals or in the content of this chapter is absent from the curriculum [66].

To sum up, the exposure of Israeli students to PG as an environmental problem is very limited and stands at about $20 \%$ of students per year. This topic is included in the curricula of two subjects only that are designed for high-school majors, and is completely absent from the rest of the school curriculum.

\section{Methodology}

This study is a mixed-methods research which uses different data sources, and uses quantitative as well as qualitative analysis to bring different perspectives while answering each question under inquiry $[67,68]$. Using a mixed-methods approach is considered more useful in answering the research questions, since it increases the possibility that the overall data collected and analyzed will be richer and more meaningful.

\subsection{Participants}

The convenience sample of the in-service teacher participants in this study, who answered the questionnaire, were recruited via mail lists of the two authors who teach both E- and non-E teachers in two different Israeli higher education institutions and have accessibility to a large number of teachers' list servers. The researchers and the assistant researcher used the list servers of teachers who fulfil the following criteria: (1) serve as educators in elementary and secondary schools in the public school education system in Israel (for this study we chose only those who have a teaching experience of at least three years); (2) have academic backgrounds in education studies; (3) hold teaching certificates in a specific field; and (4) have an academic background in an environmental-oriented field, such as geography, biology and environmental education or in a non-environmental academic field, such as arts and humanistic studies. Since the number of Israeli academic programs in environmental studies and E-teachers is much more limited in comparison to the numbers of non-environmental academic programs and non-E teachers, using these mail lists to recruit E-teachers was necessary and helpful. The low number of E-teachers in Israel also limits the sample size of this group. The non-E teacher participants were recruited via the mail lists of our research assistant, who is a teacher and has accessibility to several teachers' list servers in Israel. An e-mail was sent through the list servers, which included an explanation of the research goals and a request to participate in the study by completing a relatively short questionnaire (with mean filling-out time of about $15 \mathrm{~min}$ ) in a Qualtrics format for which each respondent received a book coupon to the value of ILS 50. Although the 
respondents received a financial incentive, the rate of responses to this e-mail was about $40 \%$. No clear reason was received from the teachers for not filling out the questionnaire. The final number of respondents that completed the questionnaire, filled out an informed consent form and participated in this study was 200 in total: $45 \%$ (90) of them were E-teachers who had completed their bachelor's or master's degree in academic environmental-oriented programs; and 55\% (110) of them were non-E teachers who had completed their bachelor's or master's degree in non-environmental academic programs. All of the participants have served as educators in elementary and secondary schools in the public school education system in Israel for 5-20 years.

No significant differences were found between E- and non-E teachers in the following demographic variables: the mean age of the $\mathrm{E}$ - and the non-E teachers was $41.3 \pm 9.09$ and $40.8 \pm 11.8$ years respectively. Women comprised $85.6 \%$ and $87.3 \%$ of the E- and non-E teachers respectively. These figures are a valid representation of the total women fraction among teachers in Israel [69]. Mean teaching experience was $4.30 \pm 0.949$ and $3.55 \pm 1.378$ years in E- and non-E teachers respectively. Socioeconomic status (measured on a Likert scale ranging from $1=$ very bad to $5=$ very good) was also similar among E- (3.44 \pm 0.809$)$ and non-E $(3.48 \pm 0.713)$ teachers.

For the interviews, we chose eight teachers from those who completed the questionnaire and agreed to be interviewed. Of these, seven were female teachers and one a male teacher, representing a range of characteristics in terms of age, teaching experience (5-25 years), and residence type (rural and urban areas). Four of them were E-teachers: two middle-school science teachers (grades 7-9), and two high-school science teachers (grades 10-12). One of the high-school teachers was a biology teacher for biology-major students, and one a science teacher for environmental studies-major students. The four non-E-teachers included one physics teacher, one English teacher, one literature teacher, all of whom teach in middle school (grades 7-9), and one Hebrew language teacher who teaches in high school (grades 10-12).

\subsection{Instruments}

Questionnaire. The questionnaire addressed teachers' perspectives and sense of knowing about PG as an environmental problem, and their considerations regarding embedding specific environmental topics in their teaching, including PG in two different sections. The first section included the following five questions; two closed and three open-ended: (1) Do you perceive population growth as an environmental problem? (2) Explain why you perceive or do not perceive population growth as an environmental problem; (3) if you include environmental topics in your teaching, explain what your considerations are for choosing the topics to bring into the classroom; If you do not include environmental topics in your teaching, explain what would be your considerations to include them in your teaching; (4) in your opinion, is it important to include population growth in school teaching? (5) Explain your attitude regarding including or excluding population growth in school teaching.

The second section of the questionnaire measured the perception of PG as an environmental problem using an instrument that is often used to assess perception of risk attributes and severity $[42,45,70]$. Studies show that the perceived attributes of a problem have a strong influence on its perceived severity. The perceived attributes of PG as a problem were measured in terms of (perceived) imminence, certainty, potential for personal harm, spatial proximity, emotional response to the problem and predictability. These perceptions of the attributes were found to be strong predictors of perceived overall severity. Table 2 presents the items used to measure the perceptions of risk attributes and severity, along with the scales. The comparisons between the two groups were analyzed with independent sample t-tests.

The second section of the questionnaire measured also the environmental subjective knowledge of the teachers (i.e., their sense of knowing). This measurement was adopted from [44,71], who previously used and validated this instruct. Three items were used: "I feel that I understand the reasons for various environmental problems"; "I feel that I know the solutions to environmental problems"; and, "I consider myself knowledgeable about environmental issues". The respondents were asked to 
mark the level to which they agreed with each of the statements on a 5-point scale, ranging from 1 (I don't agree at all) to 5 (I agree completely). Thus, a higher score represented better understanding of environmental issues. The Cronbach's $\alpha$ of the three items in our sample was 0.853 . The last question of the questionnaire was a request to provide the participants' contact information (e-mail, phone number) if they agree to be interviewed for the purpose of this study.

Self-report online questionnaires raise concern about their validity because of potential social desirability response bias, which can influence the relationship between predictor and criterion variables $[72,73]$. We assume that, in our case, the desirability bias was minimal, for three reasons: (1) the questionnaire was anonymous with no self-identifying information required, which is considered to yield relatively honest reports; (2) the online filling is considered to guarantee a greater sense of privacy and anonymity [74], or at least not lower [75] compared to off-line or paper versions of the same questionnaires; and (3) in the introduction to the questionnaire, we explicitly stated that "there are no correct or incorrect answers", and that "we are interested in knowing how you see things". In fact, in the pilot we did before the questionnaire was distributed, none of the questions were reported to be uncomfortable for the respondent. Therefore, we believe that the results obtained were not skewed by social desirability.

Interviews. Semi-structured interviews were conducted with eight teachers (as described above) who completed the questionnaire. The interviews focused on teachers' perspectives of PG as an environmental problem and their attitudes towards including or excluding the topic in their teaching. This added to the information that was gathered from the questionnaire. The interviewees were also asked to explain their attitudes and elaborate on the opportunities, as well as the challenges, that they envisaged concerning teaching the topic of PG. Using the information collected from the questionnaire, the researchers chose eight interviewees that would represent, to a high extent, the sample of participants in terms of their sociodemographic background and types of perspectives towards the issue of PG. Due to the limited access of the researchers to some of the interviewees, six interviews were face-to-face and two were phone interviews. These lasted about $45 \mathrm{~min}$, and were audiotaped and transcribed verbatim to allow an analysis of the full information. Based on Patton [67] (pp. 242-243), "there are no rules for sample size in qualitative inquiry. Sample size depends on what you want to know, the purpose of the inquiry, what's at stake, what will be useful, what will have credibility, and what can be done with available time and resources". Since the attitudes of the eight respondents covered the range of different views that were found within the whole data set of the respondents of the questionnaire regarding the issues at stake, and since the interviews served as a complementary tool for the questionnaire, we found the size of eight interviewees sufficient for this study.

\subsection{Data Analysis}

An inductive content analysis was conducted to identify emergent categories and major themes according to Strauss and Corbin [76] regarding teachers' responses to the five open-ended questions and to the interviews. Validation was achieved by the following phases: the authors created separately an initial set of codes for the analysis of each question. Then, they met to discuss the codes. They added and changed some of the codes during the discussion and confirmed only the revised codes that were agreed upon. Finally, they asked a third environmental education researcher to independently analyze the teachers' written responses using their revised codes. Since the analysis of the third researcher was similar to the authors' analysis, the authors confirmed the revised codes as the final ones. The differences between the proportions of various themes among the E-teachers vs. the non-E teachers were analyzed using chi-square tests, in which the (two-sided) significance level was 0.05 . 


\section{Results}

\subsection{Teachers' Perceptions of Population Growth as an Environmental Problem}

Analysis of teachers' responses to the first and second questions of the first section of the questionnaire revealed that PG was perceived as an environmental problem by more E-teachers than by non-E teachers. This difference was significant (Table 1). The explanations given by the teachers for perceiving PG as an environmental problem were categorized into three main perspectives: natural resources-centered, human-centered, and socio-ecological system-centered. These perspectives were significantly different among the E- versus non-E teachers, reflecting a higher level of systematic understanding by the E-teachers regarding the environmental crisis.

A significantly higher percentage of the E-teachers (57\%) held the broad socio-ecological system perspective, addressing PG as a major factor responsible for damaging both ecosystems and human-oriented systems. About a quarter of the E-teachers perceived PG from the narrower ecosystem-centered perspective and only $16 \%$ of them perceived PG from the narrower human-centered perspective. In contrast, only 19\% of the non-E teachers perceived PG from the broad socio-ecological system perspective. Nearly half of the non-E teachers addressed PG as an environmental problem from the narrower natural resources perspective, and about a third of them perceived PG from the narrower human-centered perspective.

Table 1. Distribution of teachers' perceptions of population growth (PG) as an environmental problem.

\begin{tabular}{|c|c|c|c|c|}
\hline Perception & Example of Explanation & $\begin{array}{c}\text { E- } \\
n=90\end{array}$ & $\begin{array}{c}\text { non-E } \\
n=110\end{array}$ & $\begin{array}{c}p \\
\text { (2-Sided) }\end{array}$ \\
\hline \multicolumn{2}{|c|}{ Population Growth (PG) Is an Environmental Problem } & $\begin{array}{c}83 \% \\
n=75\end{array}$ & $\begin{array}{c}61 \% \\
n=67\end{array}$ & 0.001 \\
\hline $\begin{array}{l}\text { Natural-resources } \\
\text { centered: } \mathrm{PG} \text { is the major } \\
\text { reason for natural } \\
\text { resources depletion }\end{array}$ & $\begin{array}{l}\text { More people compete for the same } \\
\text { natural resources, use the ecological } \\
\text { system services and damage it }\end{array}$ & $\begin{array}{c}20 \\
(27 \%)\end{array}$ & $\begin{array}{c}31 \\
(46 \%)\end{array}$ & 0.022 \\
\hline $\begin{array}{l}\text { Human-centered: PG } \\
\text { decreases human quality } \\
\text { of life in diverse aspects } \\
\text { (e.g., physically, } \\
\text { health-wise, socially, } \\
\text { economically) }\end{array}$ & $\begin{array}{l}\text { High population density decreases } \\
\text { quality of life, private and public } \\
\text { open spaces } \\
\text { High population density exists in low } \\
\text { socioeconomic status families who } \\
\text { cannot provide appropriate resources } \\
\text { for their children and consequently } \\
\text { become a burden; high population } \\
\text { density often comes with poverty, } \\
\text { crime and violence, creating a bad } \\
\text { influence on the broader society }\end{array}$ & $\begin{array}{c}12 \\
(16 \%)\end{array}$ & $\begin{array}{c}23 \\
(34 \%)\end{array}$ & 0.018 \\
\hline $\begin{array}{l}\text { Socio-ecological system } \\
\text { centered: PG influences } \\
\text { both the ecosystems and } \\
\text { human-oriented systems }\end{array}$ & $\begin{array}{l}\text { Currently, encouraging birthrate is } \\
\text { getting more extreme and directly } \\
\text { affects the biosphere and individuals' } \\
\text { daily life and well-being }\end{array}$ & $\begin{array}{c}43 \\
(57 \%)\end{array}$ & $\begin{array}{c}13 \\
(19 \%)\end{array}$ & $<0.001$ \\
\hline
\end{tabular}

Sixteen percent of the E-teachers and $33 \%$ of the non-E teachers did not perceive PG to be a problem. They indicated a number of reasons for not perceiving PG as a problem at similar levels in both groups. The absolute frequencies of those reasons were too small to have enough statistical power to demonstrate significant differences. All these reasons were human-centered in nature, addressing mainly sociocultural, religious, political or economic aspects and, in most cases, they ignored the human damage to the environment, thus reflecting a relatively narrow perspective. The foremost reason given by the teachers related to the unequal distribution of the population in Israel. The teachers who expressed this view believe that the PG problem does not exist in Israel, since there are many 
unpopulated spaces; in particular, the large area of the country in the Negev desert. For example, a non-E teacher stated: "The Negev is not densely populated at all. The solution is to better disperse the population across the rural areas of Israel." This perception ignores the existing high-density areas, mostly in the center of the country, and does not take into consideration the difficult living conditions in the desert that may explain the low population in that area.

Other teachers claimed that the problem is not the PG itself, but rather the insufficient infrastructure and services that are provided by the governmental organizations to the growing population in Israel. For example, a non-E teacher explained:

In itself, population growth is a positive thing. The problem is created if services such as education, health and road infrastructures are insufficient for the growing population. There are economic and social consequences for this inadequacy. For example, a low number of doctors per capita, as in developing countries, creates a suboptimal reality; or a lack of schools creates a high number of students per classroom, causing a decrease in the quality of education provided.

Many teachers addressed political and demographic reasons for the need to increase the Jewish population in Israel. For example, some of them emphasized that a large Jewish population in Israel is needed to keep Jews as the dominant population in relation to other minorities who live in the country. Similarly, others indicated that a Jewish PG is needed for defense reasons: "Population growth might indeed be problematic. However, in our small county, surrounded by many enemies, the [Jewish] culture of population growth is a blessing. We need to think of ways that it will not cause damage" (non-E teacher). Some of the teachers highlighted their support for Jewish PG in Israel as a survival response of the Jewish people to the genocide that happened to them during the Second World War, pointing out that PG is crucial "after what happened to us in the Holocaust" (non-E teacher).

Some other teachers addressed the human right to live and reproduce, claiming that PG cannot be perceived as a problem, but as a natural, required phenomenon: "Humans are supposed to live on Earth ..." (non-E teacher); "Having children is not a 'problem' - it's a natural human phenomenon" (E-teacher).

Others teachers addressed sociocultural aspects, noting that encouraging birthrate and having children is a dominant social norm rooted in Israeli society: "According to Israeli mentality, it's a blessing to have large families" (E-teacher). They further added that this norm would be hard to change. Some other teachers, from both groups, claimed that focusing on reducing PG is not the right way to solve environmental problems, and instead of focusing on the number of people that live on Earth, the focus should be on lifestyle changes and consumption habits. The following examples demonstrate this perception: "The ecological footprint of a large environmentally-oriented family could be much smaller than that of a small non-environmentally-oriented family" (E-teacher); "The way we use natural resources is the problem. Through education, we can reduce consumption and decrease environmental damage" (E-teacher).

These perceptions emphasize that even E-teachers struggle with the dilemma between the need to control birthrate and the sociocultural norms that encourage birthrate when they are confronted with the conflicting aspects that are inherent in the issue of PG. Perceiving changes in lifestyle without reducing birthrate level as the best solution to sustainability, as some of these teachers indicated, could be seen as avoiding uncomfortable responsibility. Only $1 \%$ of the E-teachers and $5 \%$ of the non-E teachers had no clear opinion concerning this issue.

Analysis of the teachers' assessment of the severity of PG as an environmental problem as reported in the second section of the questionnaire revealed that PG was perceived as more severe by E-teachers than by non-E teachers (Table 2).

Table 2 shows that the E-teachers perceived PG as more certain, imminent, proximate and personally relevant than the non-E teachers. In addition, PG evoked stronger negative emotions in E-teachers than in non-E-teachers. Overall severity was also perceived more highly in E- than in non-E teachers. It is worth noting that, unlike the E-teachers, among non-E teachers almost none of the means of perceived attributes and severity exceeded 4 , the midscale of 1-7, which designates neutral response.

Analyzing the teachers' sense of environmental knowing (subjective knowledge) revealed that the mean subjective knowledge of the E-teachers was significantly higher $(<0.001)$ than that of the 
non-E teachers (Table 3). Based on our point of departure, presented in the introduction, that the E-teachers have been constructively and explicitly exposed to the topic of PG during their studies in academic environmental-oriented programs (in contrast to the non-E teachers, who probably were not)), it is reasonable to assume, with some degree of caution, that the mean subjective knowledge of the E-teachers specifically concerning PG will also be higher than that of the non-E teachers.

Table 2. Perceptions of the attributes and overall severity of PG by E- vs. non-E teachers *.

\begin{tabular}{|c|c|c|c|c|}
\hline $\begin{array}{l}\text { Perceived } \\
\text { Attribute of PG }\end{array}$ & Item & $\begin{array}{c}\mathrm{E}- \\
n=90\end{array}$ & $\begin{array}{c}\text { non-E } \\
n=110\end{array}$ & $\begin{array}{c}p \\
(2-\text { Sided) }\end{array}$ \\
\hline Certainty & $\begin{array}{l}\text { In your opinion, to what degree } \\
\text { does PG pose a certain threat to } \\
\text { humans and the environment? }\end{array}$ & $4.58 \pm 1.824$ & $3.35 \pm 1.845$ & $<0.001$ \\
\hline $\begin{array}{l}\text { Geographical } \\
\text { proximity }\end{array}$ & $\begin{array}{l}\text { In your opinion, does PG } \\
\text { directly affect the place where } \\
\text { you live? }\end{array}$ & $4.70 \pm 1.93$ & $3.26 \pm 1.999$ & $<0.001$ \\
\hline Imminence & $\begin{array}{l}\text { In your opinion, to what extent } \\
\text { does PG pose an immediate } \\
\text { danger to humans and their } \\
\text { natural environment? }\end{array}$ & $4.00 \pm 1.884$ & $2.71 \pm 1.650$ & $<0.001$ \\
\hline Personal harm & $\begin{array}{l}\text { In your opinion, to what extent } \\
\text { do the negative effects of PG } \\
\text { pose a threat to you personally? }\end{array}$ & $4.32 \pm 1.954$ & $2.99 \pm 1.758$ & $<0.001$ \\
\hline $\begin{array}{l}\text { Emotional } \\
\text { involvement }\end{array}$ & $\begin{array}{l}\text { In your opinion, to what extent } \\
\text { does PG cause you to experience } \\
\text { a negative emotion (such as } \\
\text { sadness, anger, fear, disgust)? }\end{array}$ & $4.33 \pm 1.937$ & $3.07 \pm 1.929$ & $<0.001$ \\
\hline Predictability & $\begin{array}{l}\text { In your opinion, to what extent } \\
\text { can PG and its effect on humans } \\
\text { and their natural environment } \\
\text { be anticipated? }\end{array}$ & $5.12 \pm 1.688$ & $4.66 \pm 1.917$ & 0.077 \\
\hline Overall severity & $\begin{array}{l}\text { To what extent do you see PG as } \\
\text { a serious problem? }\end{array}$ & $4.76 \pm 1.969$ & $\begin{array}{l}3.62 \pm 1.756 \\
\quad<0.001\end{array}$ & $<0.001$ \\
\hline
\end{tabular}

${ }^{*}$ Each scale ranged from $1=$ not at all to $7=$ absolutely. ${ }^{* *}$ two-sided $t$-test.

Table 3. Comparison of subjective knowledge of E-teachers vs. non-E teachers.

\begin{tabular}{lccc}
\hline \multicolumn{1}{c}{ Variable } & \begin{tabular}{c} 
E- \\
\multicolumn{1}{c}{ n }
\end{tabular} & $\begin{array}{c}\text { non-E } \\
\boldsymbol{n = 1 1 0}\end{array}$ & $\begin{array}{c}\boldsymbol{p} \\
\text { (2-Sided) }\end{array}$ \\
\hline $\begin{array}{l}\text { I feel that I understand the reasons for various } \\
\text { environmental problems. }\end{array}$ & $4.03 \pm 0.741$ & $3.27 \pm 1.022$ & $<0.001$ \\
$\begin{array}{l}\text { I feel that I know the solutions to environmental } \\
\text { problems. }\end{array}$ & $3.09 \pm 0.816$ & $2.62 \pm 0.898$ & $<0.001$ \\
$\begin{array}{l}\text { I consider myself as knowledgeable in } \\
\text { environmental issues matters. }\end{array}$ & $3.62 \pm 0.856$ & $2.62 \pm 0.898$ & $<0.001$ \\
Mean subjective knowledge & $\mathbf{3 . 5 8} \pm \mathbf{0 . 6 7 5}$ & $\mathbf{2 . 8 6} \pm \mathbf{0 . 8 5 8}$ & $<\mathbf{0 . 0 0 1}$ \\
\hline
\end{tabular}

\subsection{Teachers' Considerations for Teaching Environmental Topics}

Analyzing teachers' considerations for including environmental topics in their teaching (the third question of the questionnaire) yielded three types of considerations, which are presented in Table 4: issue-oriented, student-oriented and teacher-oriented.

The teachers' issue-oriented considerations were similar (40\%-45\%) among E- and non-E teachers. In other words, the severity of specific problems and the urgency to address them was perceived as a good reason to expose them to their students by all the teachers, regardless of their academic 
background. Similarly, a high percentage of $E$ and non-E teachers (54\%-60\%) noted that the opportunity to develop the environmental citizenship of the students was their main reason for introducing specific issues. This similarity may indicate that all teachers, regardless of their background in environmental education, have high expectations that their students be environmentally knowledgeable, concerned citizens, engaged in society and should become effective agents of change for their own as well others' environmental behavior.

Two considerations were found to be significantly different between the teacher groups. Strong connectedness of the topics to students' emotions, daily lives and surroundings was noted as a main reason for bringing environmental issues into the classroom significantly more often by E-teachers than by non-E teachers $(p=0.03)$. This may indicate that the E-teachers were more aware of the connection of specific environmental issues to students' lives than the non-E teachers. Similarly, the E-teachers, significantly more than non-E teachers $(p=0.02)$, addressed the connectedness of the topics to their own daily lives, interests and pedagogical content knowledge as a reason for introducing these issues in the classroom. It may reflect a higher environmental awareness of the E-teachers to environmental problems, as well as higher confidence levels and better preparedness to address environmental topics in their teaching.

Table 4. Distribution of teachers' considerations for including environmental topics in their teaching.

\begin{tabular}{|c|c|c|c|c|}
\hline Considerations & $\begin{array}{c}\text { E- } \\
n=90\end{array}$ & $\begin{array}{c}\text { non-E } \\
n=109\end{array}$ & $\begin{array}{c}p \\
\text { (2-Sided) }\end{array}$ & Examples \\
\hline \multicolumn{5}{|c|}{ Issue-Oriented } \\
\hline $\begin{array}{l}\text { High severity of the issues } \\
\text { as environmental problems } \\
\text { and the urgent need to } \\
\text { address them }\end{array}$ & $\begin{array}{c}36 \\
(40 \%)\end{array}$ & $\begin{array}{c}49 \\
(45 \%)\end{array}$ & 0.56 & $\begin{array}{l}\text { During recent years, Israel is drying } \\
\text { out... We need to increase students' } \\
\text { awareness to this acute problem and } \\
\text { the need to find solutions (non-E). } \\
\text { We can improve or worsen the } \\
\text { situation. Awareness of the } \\
\text { connection between consumer culture } \\
\text { and global warming and drought is } \\
\text { important (E). }\end{array}$ \\
\hline \multicolumn{5}{|c|}{ Student-Oriented } \\
\hline $\begin{array}{l}\text { Suitability and effectiveness } \\
\text { of the topics in developing } \\
\text { students' environmental } \\
\text { citizenship } \\
\text { (knowledgeability, } \\
\text { awareness, own behavior } \\
\text { and influence on others) }\end{array}$ & $\begin{array}{c}49 \\
(54 \%)\end{array}$ & $\begin{array}{c}65 \\
(60 \%)\end{array}$ & 0.48 & $\begin{array}{l}\text { It is possible to explain the damage } \\
\text { that occurs as a result of littering ... } \\
\text { teaching this topic could easily } \\
\text { change students' own behavior and } \\
\text { hopefully prevent further damage to } \\
\text { the environment (non-E). } \\
\text { Students can protect animals } \\
\text { themselves ... they can influence the } \\
\text { behavior of other children as well as } \\
\text { adults' behavior towards animals (E). }\end{array}$ \\
\hline $\begin{array}{l}\text { Strong connectedness of the } \\
\text { topics to students' emotions, } \\
\text { daily lives, and } \\
\text { surroundings }\end{array}$ & $\begin{array}{c}33 \\
(37 \%)\end{array}$ & $\begin{array}{l}22 \% \\
(24)\end{array}$ & 0.03 & $\begin{array}{l}\text { This topic of loss of biodiversity is } \\
\text { more interesting for children (non-E). } \\
\text { Most children connect with animals } \\
\text { and can understand the direct } \\
\text { connection between the decrease in } \\
\text { open spaces and loss of biodiversity. } \\
\text { This topic is tangible ... (E). }\end{array}$ \\
\hline \multicolumn{5}{|c|}{ Teacher-Oriented } \\
\hline $\begin{array}{l}\text { Strong connectedness of the } \\
\text { topics to teachers' daily } \\
\text { lives, interests and } \\
\text { pedagogical content } \\
\text { knowledge of the topic }\end{array}$ & $\begin{array}{c}19 \\
(21 \%)\end{array}$ & $\begin{array}{c}10 \\
(9 \%)\end{array}$ & 0.02 & $\begin{array}{l}\text { Air pollution is the problem that most } \\
\text { concerns me (non-E). } \\
\text { This issue [water pollution] is part of } \\
\text { the curriculum. I'm familiar with it } \\
\text { and know exactly what should be } \\
\text { emphasized to the students (E). }\end{array}$ \\
\hline
\end{tabular}


The results suggest that higher environmental knowledgeability and/or previous experience in teaching environmental issues increases the E-teachers' confidence to teach environmental topics. It could also reflect the higher environmental awareness of the E-teachers to local problems in their living surroundings.

\subsection{Teachers' Attitudes towards Including Population Growth as an Environmental Problem in Their School Teaching}

Analyzing the teachers' attitudes regarding this issue (questions 4 and 5 in the questionnaire) yielded two supportive attitudes, one opposing attitude and a small fraction of unclear attitudes. Significant differences $(p<0.001)$ were found between the E- and non-E teachers regarding their attitudes towards the inclusion of PG in their school teaching, as presented in Table 5.

According to Table 5, the percentage of the teachers who support including PG in their teaching (i.e., the supporters) was significantly higher among the E-teachers than the non-E teachers. Accordingly, the percentage of the teachers who did not support including PG in their teaching (i.e., the opponents) was significantly lower among the E-teachers than the non-E teachers. A relatively small percentage of the teachers from both groups perceived that teaching this topic is age-dependent, and supported including PG only in secondary schools (i.e., the age-dependent-supporters), with significant differences between the E- and the non-E teachers. Only $2 \%$ of the E-teachers and $9 \%$ of the non-E teachers reported that they do not have a clear opinion regarding this issue. These findings suggest that an academic background in environmental studies contributes to teachers' motivation, willingness, and probably their teaching capacities and confidence, to include such a complex topic in their school teaching.

Table 5. Distribution of teachers' attitudes regarding inclusion of population growth in school teaching.

\begin{tabular}{lccc}
\hline \multicolumn{1}{c}{ Teachers' Attitudes } & E-Teachers $(\boldsymbol{n}=\mathbf{8 8})$ & Non-E Teachers $(\boldsymbol{n}=\mathbf{9 3})$ & $\boldsymbol{p}$ (2-Sided) \\
\hline Supporters: Support inclusion of PG in teaching & $59(67 \%)$ & $39(42 \%)$ & 0.001 \\
Age-dependent supporters: Support inclusion of & $15(17 \%)$ & $5(5 \%)$ & 0.017 \\
PG only in secondary schools & $12(14 \%)$ & $41(44 \%)$ & $<0.001$ \\
Opponents: Do not support inclusion of PG in & $2(2 \%)$ & $8(9 \%)$ & 0.101 \\
teaching & & & \\
Not sure: Do not have clear opinion & &
\end{tabular}

Table 6 presents the main explanations of the teachers for supporting or not supporting the inclusion of PG in their teaching, with a few examples taken from the questionnaire for each attitude. Despite the significant differences found between the E- and non-E teachers regarding the attitudes towards including PG in teaching (Table 5) explained above, their types of explanations did not differ.

The supporters focused mainly on the students in their explanations. All of them perceived including this topic in the classroom as an opportunity to deepen their students' understanding and awareness of the connection between PG and the environmental crisis. About a quarter of the supporters viewed teaching PG as an opportunity to discuss different ways to solve environmental problems. About $10 \%$ of the supporters viewed including this topic in their teaching as an opportunity to increase students' willingness to act pro-environmentally, currently and in the future.

The age-dependent-supporters (i.e., $17 \%$ of the E- and 5\% of the non-E teachers) focused on the nature of the topic and on the students in their explanations. Most of them agreed that this topic is too hard to discuss in elementary schools, since it is very complex and raises serious socio-ecological conflicts. Nearly $30 \%-40 \%$ of the age-dependent-supporters explained that teaching this topic at elementary school level can raise, among young children, negative feelings such as fear, anger and even helplessness concerning a topic that they themselves cannot control.

The opponents (i.e., $14 \%$ of the E- and $44 \%$ of the non-E teachers) focused on the nature of topic and on their own teaching challenges in their explanations. Nearly half of these teachers explained that this topic is irrelevant to students' everyday lives. About a third of the opponents admitted that they do not have the appropriate knowledge or teaching skills to discuss this complex topic with their 
students. About $10 \%$ of them addressed the controversial nature of the topic as their main reason for excluding it from their teaching. Finally, less than $10 \%$ of the opponents noted that they do not perceive PG as a problem at all and, therefore, will not discuss this topic in the classroom as an example of environmental problems.

The analysis of the interviews supports the findings discussed above and reinforces the picture obtained concerning teachers' attitudes towards and concerns about including PG as an environmental problem in their school teaching. Among all the eight interviewees, only the teacher of environmental studies for high school majors reported that, despite the sensitivity of the topic in Israeli society, she explicitly addresses PG as an environmental problem and discusses the complexity, controversiality and multi-faceted nature of the topic with her students:

This is a Jewish cultural issue. Because so many times [people] have tried to exterminate [the Jewish people] ... discussing demography in Israel is taboo ... But, I can't ignore this topic, not only because it's part of the curriculum, but because I must discuss the effect of global population on the natural resources that are available to us ... Discussing population growth with my students is the basis for my role as a teacher; changing moral values, encouraging them to think a few steps ahead and weigh the consequences of everything they do. Also in regard to the issue of population growth-how many children they should have and will they be able to manage their family in a sustainable way... The fact that I teach it proves that everything is a matter of exposure. It is important that the public is exposed to this topic. We cannot avoid a public discourse on it.

This example emphasizes how including the topic of PG in the core curriculum encourages teachers to not only include this topic in their teaching, but also to dig deeper into its controversiality without fear. It also demonstrates that such teachers view themselves as agents of change in terms of changing students' awareness and behavior as future citizens in order to create practical solutions for addressing the problem of PG.

The other three science teachers were more cautious and doubtful, and questioned their role as agents of change in the context of PG. They agreed that PG is an environmental problem, to some extent in Israel too, but admitted that, even during teaching topics which are directly connected to population growth and density, such as "ecological footprints", they avoid an explicit discussion about PG as a problem, which should be practically addressed. They provided several explanations: Some of them explained that they are concerned or feel uncomfortable about dealing with PG, as it may contradict cultural norms, religious values or the political, demographic agenda of the pronatalistic Israeli government due to the ongoing Arab-Jewish political dispute. Others preferred to avoid students' or parents' resistance that could arise as a result of discussing the controversial options that are available if the problem of PG is to be addressed. The biology teacher added that more scientific data about the severity of PG as a problem in Israel would encourage her to include explicit discussions about it with her students. The following quote by one of the middle-school science teachers demonstrates these attitudes:

I can't talk about PG without giving the students the necessary scientific background ... it's too far of a jump... In Israel, you can't say, "Don't have children ... small or child-free families are not viewed positively by Israeli society ... and the feeling in our country is that it's better not to talk about controversial topics that have political consequences ... it's the "Jewish uterus" versus the "Arab uterus" ... I agree that if you discuss different alternatives for creating a sustainable society, you can somehow bring $P G$ into the classroom.

Among the four non-E teachers, only the Hebrew-language high school teacher agreed that PG is an environmental problem and should be explicitly discussed with students, with an emphasis on the problem and its solutions. She highlighted the importance of engaging students in social dilemmas related to Israeli society and developing critical thinking, and gave some examples from her own teaching:

Several times, I brought to the classroom different dilemmas that are highly relevant in Israel, such as how important is it to serve in the IDF [Israel Defense Forces]. I agree that discussing PG is also a relevant 
issue in Israeli society. I'm not afraid of causing conflicts in class. It's good to discuss a topic that raises objections-it's an opportunity to hear different voices and positions ... PG should definitely be included in social studies in school; ignoring such an issue is like" sticking your head in the sand".

This quote illustrates how PG could be brought into the classroom in diverse disciplines when the teacher feels confident to do so. It raises the question of the conditions required to encourage more non-E teachers to do so.

Table 6. Teachers' explanations for supporting vs. not supporting the inclusion of population growth in school teaching.

\begin{tabular}{|c|c|}
\hline Attitude & Example of Explanation \\
\hline \multicolumn{2}{|c|}{ Support Inclusion of PG in Teaching } \\
\hline $\begin{array}{l}\text { Deepening student understanding and awareness of } \\
\text { the influence of population growth on the } \\
\text { environment }\end{array}$ & $\begin{array}{l}\text { It's important to explain the connection to the environment and } \\
\text { the implications of population density on problems such as } \\
\text { pollution, decrease of [open] spaces, damage to animal species, } \\
\text { increased waste ... E). } \\
\text { The discussion with the students should focus on the interrelated } \\
\text { environmental, social and political implications of PG (non-E). }\end{array}$ \\
\hline Focusing on solutions to environmental problems & $\begin{array}{l}\text { It's important to seek solutions to this problem. Education is the } \\
\text { key. Today's students are tomorrow's responsible parents } \\
\text { (non-E). } \\
\text { Youngsters should understand human impact on the } \\
\text { environment and what can be done to reduce our ecological } \\
\text { footprint (E). }\end{array}$ \\
\hline Encouraging students to act pro-environmentally & $\begin{array}{l}\text { It's an opportunity to discuss different ways to manage with the } \\
\text { population density, such as using public transportation, saving } \\
\text { water, reducing waste and being considerate to others in the } \\
\text { public sphere (non-E). } \\
\text { This is a very sensitive topic. With young children, I would focus } \\
\text { on changing consumption habits (E). }\end{array}$ \\
\hline \multicolumn{2}{|c|}{ Support Inclusion of PG only in Secondary Schools (Age Dependent) } \\
\hline Can raise negative feelings among young children & $\begin{array}{l}\text { This issue should be introduced gradually. We need to be careful } \\
\text { not to stress youngsters and lead them to believe that human } \\
\text { reproduction is bad (non-E). } \\
\text { Young children may feel they are a burden to the world and, } \\
\text { even though it may be true from an environmental perspective, } \\
\text { they shouldn't feel like that at their age (E). } \\
\text { It is unnecessary to generate anxiety among young children } \\
\text { (non-E). }\end{array}$ \\
\hline Too complex for elementary school students & $\begin{array}{l}\text { It depends on students' age and ability to understand the } \\
\text { complexity of the problem. I would discuss this topic with older } \\
\text { students and connect it to other subjects, such as citizenship and } \\
\text { history studies (E). }\end{array}$ \\
\hline \multicolumn{2}{|c|}{ Do not Support Inclusion of PG in Teaching } \\
\hline Topic irrelevant to children's lives & $\begin{array}{l}\text { It's more relevant to increase students' awareness and } \\
\text { responsibility to environmental issues that they can handle } \\
\text { themselves, such as caring for animals (non-E). }\end{array}$ \\
\hline A controversial and complex topic & $\begin{array}{l}\text { Including this issue in the education system is very complex. It } \\
\text { could generate conflicts with other social norms and values. I'm } \\
\text { concerned that it is impossible to discuss this issue deeply (E). }\end{array}$ \\
\hline Population growth is not a problem & $\begin{array}{l}\text { I don't view the population growth in Israel as a severe problem. } \\
\text { It's more relevant to encourage students to take responsibility } \\
\text { regarding problems that they can actually address in their daily } \\
\text { lives (non-E). } \\
\text { The Israeli army needs soldiers; one child per family is not } \\
\text { enough (non-E). }\end{array}$ \\
\hline $\begin{array}{l}\text { Teachers' lack of knowledge and teaching skills } \\
\text { related to the topic }\end{array}$ & $\begin{array}{l}\text { I don't know enough about this subject (non-E). } \\
\text { It's important to do so, but I don't know how to introduce the } \\
\text { subject to my students (E). }\end{array}$ \\
\hline
\end{tabular}


The three other non-E teachers did not perceive PG as a problem. Two of them noted that having children is a human right and should be considered a blessing and not a problem. Although they agreed that high population density could impact natural resources and cause problems such as air pollution, they still did not define PG as a problem. One of them addressed human behavior as the optimal solution to environmental problems, and not the management of PG. These three teachers do not discuss PG in the classroom and did not see it as a necessary issue or part of their role as teachers. This is reflected in the following quote by the physics teacher: "Talking about our ecological footprint and how to be more 'green' in our lifestyle —yes! Talking about population growth—no! What can we say to our students? I'm against birth control-it became a very bad problem in China.

\section{Discussion}

This study identifies the perspectives of E- and non-E teachers towards population growth as an environmental problem and their attitudes and concerns about addressing this issue in school teaching. We found significant differences between the groups in three aspects: (1) the perception of $P G$ as a problem using a broader perspective (Table 1)-A higher percentage of E-teachers compared to non-E teachers held a broad socio-ecological system perspective concerning PG as an environmental problem; (2) the perceived severity of PG (Table 2)-PG as an environmental problem was perceived as significantly more severe by E-teachers than by non-E teachers in terms of its imminence, certainty, potential for personal harm, spatial proximity, emotional response to the problem and predictability; and (3) sense of environmental knowing (Table 3)-the mean subjective environmental knowledge was significantly higher among E-teachers than among non-E teachers in terms of knowledgeability and understanding of the reasons for and the solutions to environmental issues. These findings imply that the E-teachers' capability to view environmental issues through a "whole system" lens was greater, probably reflecting the effect of their previous environmental studies on their higher systems thinking concerning environmental issues. Based on the teachers' perceptions of PG as an environmental problem and their explanations for their perceptions, most of the non-E teachers did not address both the ecological and social aspects of the ecosystems simultaneously in their explanations. Part of them focused on the effect of PG on the ecological aspects and others acknowledged the effect of PG on human life from a mainly sociocultural aspect. In total, about $80 \%$ of the non-E teachers did not connect the two components. In contrast, most of the E-teachers made a strong connection between the natural resources and social aspects that are influenced by PG, reflecting a better understanding of the cause-effect relationship. Developing systems thinking concerning environmental problems is crucial for individuals' abilities to solve real-world problems and make better informed decisions [77,78]. This systems thinking includes several characteristics, such as the ability to identify the components of a system and the processes within the system, the ability to identify dynamic relationships within the system, the ability to identify hidden dimensions of the system and the ability to think temporally [79].

The assessment of PG as a more severe environmental problem by the E-teachers, as found in this study could reflect the influence of their previous environmental studies on their more developed systems thinking concerning the characteristics of socio-ecological systems and the strong interrelations between the ecological and social components of systems in our world. It is reasonable to assume that, based on their environmental background and knowledgeability, they were more capable of viewing PG as a bigger risk in comparison to the non-E teachers. Risk experts agree that lay populations are more biased and have misconceptions in their ecological risk evaluation in comparison to those who have previously been exposed to environmental studies [41,80-82].

Our findings point to the need to expose non-E teachers to environmental studies as part of their teacher training to develop their systems thinking and their capability to perceive and assess environmental risks from a broader and more critical perspective. This exposure should be implemented in such a way that they can understand the strong relationship between the ecological and social components of systems in our world and evaluate the severity of various problems and the need to address them on a more informed level. This, in turn, would lead teachers who lack an 
environmental background to view environmental issues as more connected to various aspects of life besides the ecological aspects, which may be seen as less relevant to their own lives. Ecological risk experts have found that people decide to be proactive or change their behavior mainly due to the recognition of a clear danger that poses a risk to themselves $[41,44,83]$. It is especially important in relation to PG, since only individuals with developed systems thinking recognize it as a clear danger, as we found among the E-teachers. For teachers, recognizing PG as an environmental problem that is as part of the larger context of the socio-ecological system is a first step in their considerations towards addressing this issue in class. We discuss this further below.

The significantly stronger positive attitudes of the E-teachers towards including PG in their teaching could be connected to their stronger sense of environmental knowing and their clearer perspectives concerning PG as an environmental problem, as found in this study. It seems that these perspectives, along with their sense of knowing, contributed to the E-teachers' willingness, motivation, preparedness and decision-making to include the topic in class. Previous studies that have explored the connection between environmental subjective knowledge and environmental behavior concerning adults $[84,85]$ or among students in higher education $[44,86]$ found that a strong sense of ownership, especially around environmental problems and solutions, was an important predictor of pro-environmental behavior. In our study this tendency may have affected the pedagogical decision-making of the E-teachers concerning dealing with PG in the classroom. Additionally, since previous studies in environmental education have found a relatively high correlation between objective knowledge (knowledge de facto) and subjective knowledge (sense of knowing) $[44,86]$, we can assume that the relatively stronger sense of knowing we found among the E-teachers probably reflects their higher objective knowledge.

Our findings point out that at least half of the teachers, regardless of their academic background, choose environmental topics to include in their teaching according to their suitability for developing students' environmental citizenship, which includes influencing the students' own behavior as well as the behavior of others. This finding is encouraging. It indicates that teachers, regardless of the discipline or the age of students they teach, expect them to become agents of change in protecting the environment. Developing students' environmental citizenship as individuals is a major goal of environmental education $[87,88]$ and is considered key for achieving sustainability. The question of whether these teachers view PG as a relevant component of environmental citizenship is discussed below.

Two types of considerations were more prevalent among the E-teachers when choosing environmental topics to integrate into the classroom: the connectedness of the topics to students' emotions and daily lives, and the connectedness of the topics to their own daily lives, interests and pedagogical content knowledge. This finding indicates that E-teachers were more aware of the connection of specific environmental issues to their students' lives and to their own lives than the non-E teachers. Additionally, it reflects the fact that the E-teachers better identify different problems they see in their surroundings as environmental problems. It also suggests that environmental background and/or previous experience in teaching environmental issues increases the E-teachers' confidence to teach environmental topics and reflects a higher self-perception of being capable, skilled and prepared to teach such topics in comparison to the non-E teachers. The findings discussed above raise the question of why most teachers avoid including this topic in their teaching, even if they are knowledgeable about the topic and its direct contribution to the environmental crisis. We address this question further on.

As discussed above, the E-teachers differed from the non-E teachers in their more positive attitudes towards the inclusion of PG in school teaching (Table 4). This finding suggests that an academic background in environmental studies contributes not only to a better understanding of PG as an environmental problem, but also to a better understanding of the importance of including the topic in the classroom. It also indicates that a background in environmental studies increases teachers' motivation, willingness, and probably their teaching capacity and confidence in including such a complex topic in their school teaching. However, the similar considerations of both E- and 
non-E teachers and the similar concerns that most of the teachers reported regarding engaging their students in such a sensitive and controversial issue, suggests that knowledgeability about the subject is not enough. Sociocultural norms and values, national pronatalist political ideologies, religiosity and the absence of PG in the public discourse and in governmental policies serve as strong inhibitors to teaching this issue, even for those who are highly knowledgeable and/or aware of the severity of PG as an environmental problem. Additionally, the high motivation and willingness of the environmental studies high-school teacher to include PG in her teaching, and the fact that she was the only interviewee who actually includes meaningful discussions concerning PG in the classroom, illustrates how an explicit inclusion of a topic in the school curriculum can create a positive attitude towards teaching such an issue and using it to develop critical and systems thinking among students. It also increases the legitimacy to debate with students on this issue.

To overcome teachers' challenges of including the topic of PG in their teaching and encourage the inclusion of this topic in the educational system in different countries, we identify two directions: First, creating a lobby that would increase the awareness of the public and government politicians about PG as a severe environmental problem is necessary. We call upon environmental organizations, environmental academics and activists around the world to make an effort and publicize through the media informed data about the consequences of PG on the world's socioeconomic and environmental future. This lobby could assist teachers by providing them with informed and updated knowledge about PG as a problem, which can be used in the classroom, thus addressing any lack of knowledge on the topic that some of the teachers noted as a teaching challenge. In addition, it would increase the legitimization to address this topic within the school system.

In recent years, the efforts of environmental organizations, experts and activists to make important steps in this direction have been spreading. For example, focusing on immigration, the Federation for American Immigration Reforms [89] reviewed the environmental effects of overpopulation in the U.S. and calls for achieving population stability by policy changes: "A larger population will deprive our children (and ourselves) of the enjoyment of open spaces, biodiversity, and a clean environment and it will jeopardize their standard of living. The time has come for Congress to adopt a population policy that respects the realities governing our environment and quality of life". Various organizations that seek to establish an ecologically sustainable human population are active in other developed countries, such as Sustainable Population Australia [90], the Population Institute Canada [91], the Israel Forum for Population, Environment and Society [92] and the American Center for Biological Diversity [93]. The latter directly encourages a debate about how human overpopulation crowds out species and hastens climate change through the unique and creative Endangered Species Condoms project [93]. To date, about half a million colorful packages of condoms depicting endangered animals have been distributed across the country to encourage discourse about the link between human population growth and the species extinction crisis in an innovative way. While addressing this project in the school system might not be appropriate, in teacher-training it could be a fun way to increase teachers' own awareness and understanding of PG as an environmental problem.

A second direction to assist teachers with the challenges of including the topic of PG in their teaching should be giving teachers the opportunity to gain experience with appropriate teaching strategies in order to engage students effectively in discourse about this issue. Researchers and educators of social and science studies suggest three main strategies for teachers to address controversial issues in the classroom: neutrality, balance and commitment [12,94], each having its own strengths and weaknesses. In the neutrality strategy, the teacher acts as a "neutral chair" and does not use his/her position of authority to convince students to support his/her own opinion regarding the discussed issue, hoping that the students will "get to the truth" of the issue discussed [95]. In the balanced strategy, the teacher presents a balanced picture by introducing a range of alternative options of an issue to the students. The third strategy of commitment is the one most discussed in the literature of environmental education, focusing on the teacher's role as an agent of change that is committed to promote his/her students' attitudes towards protecting the environment [12]. Teachers who adopt 
this strategy are required to make their own opinions known at the beginning of the discussion $[54,94]$ so that their students' will be aware of potential bias. Adopting this strategy offers the students an opportunity to be critical and discuss various views concerning an issue; however, it may lead some of them to adopt a specific view only because it is their teacher's view. We recommend providing teachers from different disciplines with opportunities to learn about and practice such strategies during their teaching training or during professional development programs and choose the strategy they find appropriate for them.

Science education researchers, such as Sadler, Chambers and Zeidler [96], emphasize that good instruction of socio-scientific issues-in our case, PG-requires appropriate teacher training to address the topic. This training includes teachers' gaining a deep understanding of science content related to the topic and acknowledgement of different perspectives held by students, their potential reasoning patterns and moral developments. We agree with their claims, and recommend that such teacher training and professional development should be implemented in all disciplines, not just in science or geography education.

\section{Conclusions and Implications}

In conclusion, the study shows that including PG-related issues in the school curriculum depends on the teacher's ability to overcome a unique combination of barriers: content knowledge and understanding of the problem and its implications; the teacher's recognition of the relevance of the subject to his/her own daily life, as well as to that of his/her students and the need to bring the subject into the classroom; and finally, the teacher must overcome any feelings of incompetence to address the dilemmas that the subject raises, and be able to lead a discussion and debate on the conflicts related to the subject.

In an essay entitled "Perpetual Growth: The Next Dragon Facing Biology Teachers", Hardin [17] referred to what it takes for a teacher to choose to teach a complicated and controversial subject. Referring to evolution, he wrote: "In many communities, it takes considerable courage to be a good biology teacher" (p. 73). In light of the complexity and controversiality of the issue, Hardin's statement may apply also to teaching about PG. The "dragons" facing teachers can and must be overcome. Encouraging teachers, from all disciplines, to include the PG issue in the curriculum and equipping them with the necessary knowledge, skills and pedagogical strategies are among the most important moral imperatives of the education system in a "century of declines" [97]. A review of the scientists, who acknowledge the PG problem, warn against ignoring it in the national and public discourse, and call for greater societal and research attention, shows that the problem is not limited to Israel. Scientists from different countries, such as the U.S. [17,98], Canada [99], UK [36], Sweden [62], Germany, Austria and Slovakia [100], as well as hundreds of scientists from around the world, including developed and developing countries [101], are equally concerned about the reluctance to address the PG issue. This issue should be addressed on a global scale, while taking into account the particular local characteristics of the studied society to overcome the specific political, cultural and ethical barriers that prevent recognition of the problem and look for ways to deal with it. We assume that, to a great extent, the difficulties educators face in discussing the problem is universal. Therefore, further studies on teachers' barriers and facilitators to implementing the issue in the classroom is tremendously warranted.

This study is a first step in identifying educators' perspectives concerning the issue of PG and their attitudes towards including this issue explicitly in the school curriculum. Despite the rich results obtained in this study, the type of the sample we used (i.e., convenience sample) limits our conclusions since we are not sure about the level of representativeness of the sample with respect to the sociodemographic characteristics of the participants. Further research in this direction should make the effort to mitigate such limitations and seek a better representative sample. It should also address the objective knowledge of E- and non-E educators regarding PG (in addition to their subjective 
knowledge) in terms of understanding the consequences of this socio-environmental problem as well as the environmental, social, cultural and political consequences of ways to address PG.

In view of scientists' worldwide agreement regarding the urgent need to address the consequences of PG on the environment and on human quality of life, and in view of the understanding that education plays a central role in this direction, further research in this field is needed to find ways to convince teachers that PG is a relevant, legitimate and important topic to introduce into their school teaching, and to encourage them to do so by strengthening their motivation, willingness and capabilities. Further research is also needed to explore whether the perceptions, attitudes, concerns and challenges concerning PG that were found among the E- and non-E teachers in this study are limited to Israel, or, as we described in the introduction, are of a global nature.

Author Contributions: I.A. and N.C. developed the instruments, collected the data, conducted analysis of the data, interpreted the findings and wrote the paper.

Funding: This research was funded by Tel Hai College.

Acknowledgments: The authors thank the participants for their agreement to take part in this study and for the rich data they provided. Kibbutzim College of Education Technology and the Arts is thanked for its financial support for the editing process.

Conflicts of Interest: The authors declare no conflict of interest.

\section{References}

1. Ehrlich, P.R.; Holdren, J.P. Impact of population growth. Science 1971, 171, 1212-1217. [CrossRef]

2. Hynes, H.P. Taking Population out of the Equation: Reformulating I= PAT; Institute on Women and Technology: North Amherst, MA, USA, 1993.

3. Chertow, M.R. The IPAT equation and its variants. J. Ind. Ecol. 2000, 4, 13-29. [CrossRef]

4. Waggoner, P.E.; Ausubel, J.H. A framework for sustainability science: A renovated IPAT identity. Proc. Natl. Acad. Sci. USA 2002, 99, 7860-7865. [CrossRef]

5. Diamond, J. Collapse; Penguin Books: London, UK, 2011.

6. Sherbinin, A.D.; Carr, D.; Cassels, S.; Jiang, L. Population and environment. Annu. Rev. Environ. Resour. 2007, 32, 345-373. [CrossRef]

7. Cohen, J.E. How many people can the earth support? Bull. Am. Acad. Arts Sci. 1998, 51, 24-39. [CrossRef]

8. Hayes, A.C. On defining the problem of population and environment. Presented at the Annual Meeting Population Association American, San Francisco, CA, USA, 6-8 April 1995.

9. Bridgeman, B. Population growth underlies most other environmental problems: Comment on Clayton et al. (2016). Am. Psychol. 2017, 4, 386-587. [CrossRef]

10. Ehrlich, P.R. Questions and Answers Panel, Population Increase and the Impact on Environmental Resources Workshop, 13/11/2012 Tel Aviv University, Israel. Available online: https://www.youtube.com/watch?v= C64J_sUtETc (accessed on 1 March 2019).

11. Crist, E.; Mora, C.; Engelman, R. The interaction of human population, food production, and biodiversity protection. Science 2017, 356, 260-264. [CrossRef]

12. Cotton, D.R. Teaching controversial environmental issues: Neutrality and balance in the reality of the classroom. Educ. Res. 2006, 48, 223-241. [CrossRef]

13. Ehrlich, P.R.; Ehrlich, H.A. The Population Explosion; Simon and Schuster: New York, NY, USA, 1990.

14. Howell, S.E.; Laska, S.B. The changing face of the environmental coalition: A research note. Environ. Behav. 1992, 24, 134-144. [CrossRef]

15. Orenstein, D.E. Population growth and environmental impact: Ideology and academic discourse in Israel. Popul. Environ. 2004, 26, 41-60. [CrossRef]

16. Kulczycki, A. World Population Policies: Their Origin, Evolution, and Impact. Popul. Stud. 2013, 67, $243-246$. [CrossRef]

17. Hardin, G. Perpetual Growth: The next dragon facing biology teachers. Amer. Biol. Teach. 1994, 56, $222-225$. [CrossRef]

18. Stevenson, R.B. Schooling and environmental education: Contradictions in purpose and practice. Environ. Educ. Res. 2007, 13, 139-153. [CrossRef] 
19. Bonnett, M. Education for sustainability as a frame of mind: Reprinted from Environmental Education Research (2002) 8 (1). Environ. Educ. Res. 2006, 12, 265-276. [CrossRef]

20. Mckeown, R.; Hopkins, C. Weaving sustainability into pre-service teacher education programs. In Teaching Sustainability at Universities; Filho, W.L., Ed.; Peter Lang: Frankfurt, Germany, 2002.

21. Tilbury, D.; Stevenson, B.; Fien, J.; Schreuder, D. Education for Sustainability: Responding to the Global Challenge; IUCN: Gland, Switzerland; Cambridge, UK, 2002.

22. Malthus, T.R. An Essay on the Principle of Population as it Affects the Future Improvement of Society, with Remarks on the Speculations of Mr. Goodwin, M; Johnson: London, UK, 1798.

23. The Royal Society. Population Growth, Resource, Consumption, and a Sustainable World. 1992. Available online: http:/ / dieoff.org/page7.htm (accessed on 1 March 2019).

24. Union of Concerned Citizens. 1992 World Scientists' Warning to Humanity. Available online: https: / / www.ucsusa.org/about/1992-world-scientists.html\#.XEQfsFxvbIU (accessed on 1 March 2019).

25. Bandura, A. Environmental Sustainability by Sociocognitive Deceleration of Population Growth. In The Psychology of Sustainable Development; Schmuch, P., Schultz, W., Eds.; Kluwer: Dordrecht, The Netherlands, 2002; pp. 209-238.

26. (UNEP) United Nations Environmental Programme. The Global Environment Outlook Year Book 2004/2005. 2005. Available online: http://gfmc.online/media/2005/news_20050302_unep-3.html (accessed on 1 March 2019).

27. Rees, W.E. Ecological footprints and appropriated carrying capacity: What urban economics leaves out. Environ. Urban. 1992, 4, 121-130. [CrossRef]

28. Motesharrei, S.; Rivas, J.; Kalnay, E. Human and nature dynamics (HANDY): Modeling inequality and use of resources in the collapse or sustainability of societies. Ecol. Econ. 2014, 101, 90-102. [CrossRef]

29. Bybee, R.W. Science-technology-society in science curriculum: The policy-practice gap. Theory Pract. 1991, 30, 294-302. [CrossRef]

30. Cheung, D.; Ng, P.H. Science teachers' beliefs about curriculum design. Res. Sci. Educ. 2000, 30, 357-375. [CrossRef]

31. Pielke, R.A.; Sarewitz, D. Bringing society back into the climate debate. Popul. Environ. 2005, 26, $255-268$. [CrossRef]

32. Beck, R.; Kolankiewicz, L. The environmental movement's retreat from advocating US population stabilization (1970-1998): A first draft of history. J. Policy Hist. 2000, 12, 123-156. [CrossRef] [PubMed]

33. Bartlett, A.A. Reflections on sustainability, population growth, and the environment revisited. Renew. Resour. J. 1998, 15, 6-23.

34. Pakulski, J.; Tranter, B.; Crook, S. The dynamics of environmental issues in Australia. Aust. J. Polit. Sci. 1998, 33, 235-252. [CrossRef]

35. Weld, M. Deconstructing the dangerous dogma of denial: The feminist-environmental justice movement and its flight from overpopulation. Ethics Sci. Environ. Polit. 2012, 12, 53-58. [CrossRef]

36. Coole, D. Too many bodies? The return and disavowal of the population question. Environ. Polit. 2013, 22, 195-215. [CrossRef]

37. Group of 7 Dwarfs. Future-Blind and Warning-Deaf Self-righteous Immoral Imperative Enabling Future Human Sacrifice. Population Growth as the Ignored "Elephant IN THE Room" of the Paris Climate Change Agreement (2015). 2018. Available online: https:/ / www.laetusinpraesens.org/docs10s/g7dwarfs.php\#refs (accessed on 1 March 2019).

38. Vlek, C.; Steg, L. Human Behavior and Environmental Sustainability: Problems, Driving Forces, and Research Topics. J. Soc. Issues 2007, 63, 1-19. [CrossRef]

39. Pratarelli, M.E. Myopic Man: On the Nature and Universality of Self-Deception and Its Long Term Effects on Our Environment; Medici Publication: Pueblo, CO, USA, 2008.

40. Figner, B.; Weber, E.U. Who takes risks when and why? Determinants of risk taking. Curr. Dir. Psychol. Sci. 2011, 20, 211-216. [CrossRef]

41. Slimak, M.W.; Dietz, T. Personal values, beliefs, and ecological risk perception. Risk Anal. 2006, 26, 1689-1705. [CrossRef]

42. Slovic, P. The Perception of Risk; Routledge: London, UK, 2016. 
43. Stevens, D.; Vaughan-Williams, N.; Vaughan, N. Public perceptions of security: Reconsidering sociotropic and personal threats. In Proceedings of the Annual Elections, Public Opinion and Parties Meeting, Oxford, UK, 7-9 September 2012.

44. Carmi, N.; Arnon, S.; Orion, N. Transforming environmental knowledge into behavior: The mediating role of environmental emotions. J. Env. Educ. 2015, 46, 183-201. [CrossRef]

45. Loewenstein, G.F.; Weber, E.U.; Hsee, C.K.; Welch, N. Risk as feelings. Psychol. Bull. 2001, 127, 267. [CrossRef]

46. Johnson, E.J.; Tversky, A. Representations of perceptions of risks. J. Exp. Psychol. 1984, 113, 55. [CrossRef]

47. Paterson, R.J.; Neufeld, R.W. Clear danger: Situational determinants of the appraisal of threat. Psychol. Bull. 1987, 101, 404. [CrossRef]

48. McDaniels, T.; Axelrod, L.J.; Slovic, P. Characterizing perception of ecological risk. Risk Anal. 1995, 15, 575-588. [CrossRef]

49. Axelrod, L.J.; McDaniels, T.; Slovic, P. Perceptions of ecological risk from natural hazards. J. Risk Res. 1999, 2, 31-53. [CrossRef]

50. Johnson, E.J.; Tversky, A. Affect, generalization, and the perception of risk. J. Pers. Soc. Psychol. 1983, 45, 20. [CrossRef]

51. Slovic, P.; Finucane, M.L.; Peters, E.; MacGregor, D.G. Risk as analysis and risk as feelings: Some thoughts about affect, reason, risk, and rationality. Risk Annal. 2004, 24, 311-322. [CrossRef]

52. Böhm, G.; Pfister, H.R. Consequences, morality, and time in environmental risk evaluation. J. Risk Res. 2005, 8, 461-479. [CrossRef]

53. Aldrich-Moodie, B.; Kwong, J. Environmental Education; Institute of Economic Affairs: London, UK, 1997.

54. Oulton, C.; Dillon, J.; Grace, M.M. Reconceptualizing the teaching of controversial issues. Inter. J. Sci. Educ. 2004, 26, 411-423. [CrossRef]

55. Pedretti, E.G.; Bencze, L.; Hewitt, J.; Romkey, L.; Jivraj, A. Promoting issues-based STSE perspectives in science teacher education: Problems of identity and ideology. Sci. Educ. 2008, 17, 941-960. [CrossRef]

56. Byford, J.; Lennon, S.; Russell, W.B. Teaching controversial issues in the social studies: A research study of high school teachers. Clear. House 2009, 82, 165-170. [CrossRef]

57. Noddings, N. Educating Moral People: A Caring Alternative to Character Education; Teachers College Press: New York, NY, USA, 2002.

58. Gayford, C. Controversial environmental issues: A case study for the professional development of science teachers. Inter. J. Sci. Educ. 2002, 24, 1191-1200. [CrossRef]

59. Windschitl, M. Framing constructivism in practice as the negotiation of dilemmas: An analysis of the conceptual, pedagogical, cultural, and political challenges facing teachers. Rev. Educ. Res. 2002, 72, 131-175. [CrossRef]

60. Wise, S.B. Climate change in the classroom: Patterns, motivations, and barriers to instruction among Colorado science teachers. J. Geosci. Educ. 2010, 58, 297-309. [CrossRef]

61. Schreiner, C.; Henriksen, E.K.; Kirkeby Hansen, P.J. Climate education: Empowering today's youth to meet tomorrow's challenges. Stud. Sci. Educ. 2005, 41, 3-49. [CrossRef]

62. Wynes, S.; Nicholas, K.A. The climate mitigation gap: Education and government recommendations miss the most effective individual actions. Environ. Res. Lett. 2017, 12, 074024. [CrossRef]

63. Jurow, A.S. Generalizing in interaction: Middle school mathematics students making mathematical generalizations in a population-modeling project. Mind Cult. Activ. 2004, 11, 279-300. [CrossRef]

64. Israel Ministry of Education. The Pedagogical Secretary. The Curriculum of Environmental Sciences for High School Majors. 2018. Available online: http:/ /cms.education.gov.il/EducationCMS/Units/Mazkirut _Pedagogit/MadaeHasvivva/TochnitLimudimChadash (accessed on 1 March 2019).

65. Israel Ministry of Education. The Pedagogical Secretary. The Curriculum of Geography and Environmental development studies for High School Majors. 2018. Available online: http:/ / cms.education.gov.il/Education CMS/Units/Mazkirut_Pedagogit/Geographya/elyona/TochniyotLimudim/tochnitlimudimelyona.htm (accessed on 1 March 2019).

66. Israel Ministry of Education. The pedagogical Secretary. The Curriculum of Biology studies for High School Majors. 2018. Available online: http://cms.education.gov.il/EducationCMS/Units/Mazkirut_Pedagogit /Biology/TochnitLimudim/tochnitmutemet.htm (accessed on 1 March 2019).

67. Patton, M.Q. Qualitative Research and Evaluation Methods, 3rd ed.; Sage Publications: Thousand Oaks, CA, USA, 2002. 
68. Johnson, R.B.; Onwuegbuzie, A.J.; Turner, L.A. Toward a definition of mixed methods research. J. Mix. Methods Res. 2007, 1, 112-133. [CrossRef]

69. Central Bureau of Statistics (Israel). Teaching staff in schools, by level of education and selected characteristics 2013/14. 2018. Available online: https://www.cbs.gov.il/he/publications/DocLib/2014/ShnatonEducat ion/st08_03.pdf (accessed on 1 March 2019).

70. Carmi, N.; Kimhi, S. Further than the eye can see: Psychological distance and perception of environmental threats. Hum. Ecol. Risk Assess. 2015, 21, 2239-2257. [CrossRef]

71. Carmi, N.; Arnon, S. The role of future orientation in environmental behavior: Analyzing the relationship on the individual and cultural levels. Soc. Nat. Resour. 2014, 27, 1304-1320. [CrossRef]

72. Fernandes, M.F.; Randall, D.M. The nature of social desirability response effects in ethics research. Bus. Ethics Quart. 1992, 2, 183-205. [CrossRef]

73. Zerbe, W.J.; Paulhus, D.L. Socially desirable responding in organizational behavior: A reconception. Acad. Manag. J. 1987, 12, 250-264.

74. Ben-Ze'ev, A. Privacy, emotional closeness, and openness in cyberspace. Comput. Hum. Behav. 2003, 19, 451-467. [CrossRef]

75. Dodou, D.; de Winter, J.C. Social desirability is the same in offline, online, and paper surveys: A meta-analysis. Comput. Hum. Behav. 2014, 36, 487-495. [CrossRef]

76. Strauss, A.; Corbin, J. Grounded theory methodology. Handbook of qualitative research. In Handbook of Qualitative Research; Norman, K.D., Vannaeds, S.L.Y., Eds.; Sage Publications: Thousand Oaks, CA, USA, 1994; pp. 22-23.

77. Kim, D.H.; Senge, P.M. Putting systems thinking into practice. Syst. Dynam. Rev. 1994, 10, $277-290$. [CrossRef]

78. O'Connor, J.; McDermott, I. The Art of Systems Thinking; Thorsons: London, UK, 1997.

79. Assaraf Ben Zvi, O.; Orion, N. Development of system thinking skills in the context of earth system education. J. Res. Sci. Teach. 2005, 42, 518-560. [CrossRef]

80. Willis, H.H.; DeKay, M.L.; Morgan, M.G.; Florig, H.K.; Fischbeck, P.S. Ecological risk ranking: Development and evaluation of a method for improving public participation in environmental decision making. Risk Anal. 2004, 24, 363-378. [CrossRef] [PubMed]

81. Koger, S.M.; Winter, D.D. The Psychology of Environmental Problems: Psychology for Sustainability; Psychology Press: New York, NY, USA, 2011.

82. Fischhoff, B.; Morgan, G. The science and practice of risk ranking. In Risk Analysis and Human Behavior; Fischhoff, B., Ed.; Earthscan: London, UK, 2012.

83. O'connor, R.E.; Bard, R.J.; Fisher, A. Risk perceptions, general environmental beliefs, and willingness to address climate change. Risk Anal. 1999, 19, 461-471. [CrossRef]

84. Aertsens, J.; Mondelaers, K.; Verbeke, W.; Buysse, J.; Van Huylenbroeck, G. The influence of subjective and objective knowledge on attitude, motivations and consumption of organic food. Br. Food J. 2011, 113, 1353-1378. [CrossRef]

85. Badariah, T.; Ahmed, T.; Nordin, M.S. University Students' Subjective Knowledge of Green Computing and Pro-environmental Behavior. Int. Educ. Stud. 2014, 7, 64-74.

86. Alkaher, I.; Goldman, D. Characterizing the motives and environmental literacy of undergraduate and graduate students who elect environmental programs-a comparison between teaching-oriented and other students. Environ. Educ. Res. 2018, 24, 969-999. [CrossRef]

87. UNESCO. Global Citizenship Education. Topics and Learning Objectives. 2015. Available online: https: / / unesdoc.unesco.org/ark: / 48223/pf0000232993 (accessed on 1 March 2019).

88. North American Association for Environmental Education (NAAEE). Excellence in Environmental Education: Guidelines for Learning (K-12). 2010. Available online: http:/ / resources.spaces3.com/89c197bf-e630-42b0-a d9a-91f0bc55c72d.pdf (accessed on 1 March 2019).

89. Federation for American Immigration Reform. The United States Is Already Overpopulated. 2009. Available online: http:/ / fairus.org/issue/population-environment/united-states-already-overpopulated (accessed on 1 March 2019).

90. Sustainable Population Australia. Australian Population. Available online: http://www.population.org.au (accessed on 1 March 2019).

91. Population Institute Canada. Available online: https:/ / populationinstitutecanada.ca (accessed on 1 March 2019). 
92. Trajtenberg, M.; Alterman, R.; Ben-David, D.; Perry, D.; Bechor, S.; Lev Ami, S.; Han, I.; Katz, D.; Elkan, D. A Crowded Future-Israel 2050. Available online: http:/ / population.org.il/en/4055/ (accessed on 1 March 2019).

93. Center for Biological Diversity. Tacking the Population Problem. Available online: https://www.biological diversity.org/programs/population_and_sustainability/population (accessed on 1 March 2019).

94. Council of Europe. Living with Controversy. Teaching Controversial Issues Through Education for Democratic Citizenship and Human Rights (EDC/HRE). Training Pack for Teachers. 2016. Available online: https:/ / rm.coe.int/16806948b6 (accessed on 1 March 2019).

95. Hand, M.; Levinson, R. Discussing controversial issues in the classroom. Educ. Philos. Theory 2012, 44, 614-629. [CrossRef]

96. Sadler, T.D.; Chambers, F.W.; Zeidler, D.L. Student conceptualizations of the nature of science in response to a socioscientific issue. Int. J. Sci. Educ. 2004, 26, 387-409. [CrossRef]

97. Heinberg, R. Peak Everything: Waking up to the Century of Declines; New Society Publishers: Gabriola Island, BC, Canada, 2010.

98. Ehrlich, P.R.; Ehrlich, A.H. Population, resources, and the faith-based economy: The situation in 2016. Biophys. Econ. Resour. Qual. 2016, 1, 1-9. [CrossRef]

99. Rees, W.E. Introduction to Sustainable Development—Carrying capacity and sustainability: Waking Malthus' ghost. In Encyclopedia of Life Support Systems; Bell, D.V.J., Cheung, Y.A., Eds.; 2002; Available online: https:/ / www.eolss.net/sample-chapters/C13/E1-45-04-11.pdf (accessed on 1 March 2019).

100. Schneider, U.A.; Havlík, P.; Schmid, E.; Valin, H.; Mosnier, A.; Obersteiner, M.; Fritz, S. Impacts of population growth, economic development, and technical change on global food production and consumption. Agric. Syst. 2011, 104, 204-215. [CrossRef]

101. Ripple, W.J.; Wolf, C.; Newsome, T.M.; Galetti, M.; Alamgir, M.; Crist, E. 15,364 scientist signatories from 184 countries. World scientists' warning to humanity: A second notice. BioScience 2017, 67, 1026-1028. [CrossRef]

(C) 2019 by the authors. Licensee MDPI, Basel, Switzerland. This article is an open access article distributed under the terms and conditions of the Creative Commons Attribution (CC BY) license (http:/ / creativecommons.org/licenses/by/4.0/). 